\title{
Pengaruh Aktivitas Seksual Pranikah, Ketaatan Beragama dan Sosial Ekonomi terhadap Kehamilan Remaja di Kecamatan Saptosari Gunungkidul
}

\author{
Elly Magdalena, Hari Basuki Notobroto \\ Departemen Biostatistika dan Kependudukan \\ Fakultas Kesehatan Masyarakat Universitas Airlangga \\ Alamat korespondensi: \\ Elly Magdalena \\ Email: ellymagdalena76@yahoo.com
}

\begin{abstract}
Teenage pregnancies still prevalent in rural areas with a low levels of family income. Teenage pregnancy may cause maternal mortality and infant mortality. This study was conducted to analyze the risk factors of teenage pregnancy in the District Saptosari Gunungkidul. This research used analytical observational study with case control design. Data was collected by interview with 46 teenagers, consisted of 23 pregnant teenagers and 23 nonpregnant teenagers in Saptosari Gunungkidul. The samples were taken by simple random sampling method and interviews were conducted with respondents to get the information about the variables studied. The independent variable were premarital sexual activity, religious obedience and social economic. Dependen variable in this study was teenage pregnancy. Data was analyzed using binary logistic regression ( $\alpha 0.05)$. The result showed that there was influence of religious obedience on teenage pregnancy. Teenage with low religious obedience had high risk to have teenage pregnancy than those with high level of religious obedience with OR 57,8. Teenage with low social economic had high risk to have teenage pregnancy than those with high social economic $(O R$ : 63,9). The conclusion of this research is risk factors which influence the occurrent off teenage pregnancy are religious obedience and social economic.
\end{abstract}

Keywords: teenage, pregnancy, sexual activity.

\begin{abstract}
ABSTRAK
Kehamilan remaja masih banyak terjadi di wilayah pedesaan dengan tingkat pendapatan keluarga yang rendah. Kehamilan remaja dapat menjadi penyebab kematian ibu dan kematian bayi. Penelitian ini dilakukan untuk mengetahui dan menganalisis faktor risiko kehamilan remaja di Kecamatan Saptosari Kabupaten Gunungkidul. Penelitian ini menggunakan penelitian analitik observasional. Data penelitian didapatkan dengan melakukan wawancara pada 46 remaja. Terdiri dari 23 remaja hamil dan 23 remaja tidak hamil di Kecamatan Saptosari Kabupaten Gunungkidul. Sampel diambil dengan metode simple random sampling. Variabel bebas pada penelitian ini adalah aktivitas seksual pranikah, ketaatan beragama, dan sosial ekonomi. Data dianalisis dengan menggunakan regresi logistik biner ( $\alpha$ 0,05). Menunjukkan bahwa ada pengaruh ketaatan beragama terhadap kehamilan remaja. Remaja yang tidak taat beragama memiliki risiko tinggi untuk terjadi kehamilan dibandingkan dengan remaja yang taat beragama dengan $\mathrm{P}$ value 0,000 . Remaja dengan sosial ekonomi rendah memiliki risiko tinggi untuk terjadi kehamilan dibandingkan dengan remaja dengan sosial ekonomi atau jumlah pengeluaran keluarga per bulan di atas UMK dengan P value 0,000. Faktor risiko yang berpengaruh terhadap kehamilan remaja yaitu faktor ketaatan agama dan faktor sosial ekonomi sehingga perlu dilakukan perbaikan perekonomian setempat dan peningkatan ketaatan beragama bagi remaja.
\end{abstract}

Kata kunci: remaja, kehamilan, aktivitas seksual.

\section{PENDAHULUAN}

Kehamilan remaja pada usia 15-19 tahun menurut WHO 2014 menunjukkan angka rata-rata 49 per 1000 remaja di dunia atau dengan kisaran angka 1 hingga 299 persalinan per 1000 remaja putri dengan angka tertinggi di Sahara Afrika sebagai penyandang angka tertinggi. Kehamilan remaja menjadi penyebab kematian ibu dan anak juga sebagai bagian dari siklus kesehatan dan gizi buruk. Sebesar 9\% perempuan 15-19 tahun di Indonesia pernah melahirkan bayi, yang berarti jumlahnya adalah 100 orang per 1000 remaja putri (SDKI, 2010). 
Persalinan remaja 15-19 tahun mayoritas terjadi di negara berkembang dengan angka kejadian persalinan remaja ini mencapai 95\%. Prevalensi tertinggi di Nigeria (79\%) menyusul Kongo di tempat kedua dengan $74 \%$ dan di tempat ketiga adalah Afganistan 54\% selanjutnya Bangladesh 51\%. Hal ini menunjukkan keterikatan erat antara kasus kehamilan remaja dengan keterbelakangan dan sosial ekonomi yang belum memadai (WHO, 2014).

Menurut survei Badan Pusat Statistik (BPS) Indonesia tahun 2012 angka kehamilan remaja usia 15-19 tahun adalah 48 per 1000 kehamilan. AKI dan AKB pada pertengahan 2013 adalah 359 per 100.000 kelahiran hidup dengan angka kematian bayi 32 per 1000 kelahiran hidup dan Indonesia menempati urutan ke 8 di ASEAN untuk AKI dan AKB (BPS, 2012).

Remaja memiliki rasa ingin tahu yang tinggi namun kurang disertai pertimbangan rasional akan akibat dari perbuatan yang dilakukan. Remaja yang labil dan tidak memiliki pondasi ajaran agama yang kuat dapat tidak terkendali dan melakukan seks bebas yang di larang oleh agamanya. Pada masa ini peran pendidikan agama yang sudah diajarkan sejak masa kecil menjadi kendali perilaku remaja. Penjelasan seksualitas dari sudut pandang agama, ketaatan remaja dalam menjalankan ibadah menurut agama yang dianutnya berpengaruh besar terhadap pengendalian perilaku termasuk dalam hal perilaku seksual (Salihun, 2002).

Menurut Dadang Hawari (2011), dari 10 remaja putri telah melakukan hubungan seksual sebelum mereka berusia 20 tahun dan paling sedikit telah berganti pasangan dengan 4 pria yang berbeda. Emosi tinggi dan ketertarikan kepada lawan jenis yang dialami oleh remaja menghadapkan remaja pada 2 pilihan yaitu godaan media lingkungan dan teman sebaya yang menjerumuskan. Di sisi lain mereka yakin bahwa hukum agama yang mereka anut harus ditegakkan. Dengan ketaatan beragama remaja dapat mengendalikan dirinya dan tidak melakukan seks bebas. Survey Badan Koordinasi Keluarga Berencana Nasional (BKKBN) tahun 2010 menyatakan kasus kehamilan remaja usia 14-19 tahun dengan persentase sebesar $19,6 \%$ dari total penduduk Indonesia. Lebih dari 50\% diantaranya melakukan seks bebas. Hasil survey sebanyak $30 \%$ dari remaja yang melakukan seks bebas berakhir pada kawin muda, hal ini menunjukkan bahwa banyak remaja di Indonesia belum memahami risiko kehamilan remaja (BKKBN, 2010).

Data Depkes (2006), menunjukkan Jumlah remaja usia 10-19 tahun di Indonesia adalah 43 Juta atau 19,61 dari jumlah penduduk, dan sekitar 200 ribu remaja putri atau sejumlah $1 \%$ secara terbuka menyatakan pernah melakukan hubungan seksual di luar nikah.

Menurut BKKBN (2012), dalam survey kesehatan reproduksi remaja menyatakan bahwa remaja putri yang mengaku pernah melakukan hubungan seksual di luar nikah sebanyak 34.7\% pada tahun 2003-2003 dan meningkat secara drastis hingga mencapai angka $93,7 \%$ pada tahun 2012.

Kajian pernikahan dini yang dilakukan oleh BKKBN tahun 2012 di 4 Provinsi menunjukkan bahwa Provinsi dengan persentase perkawinan dini (15-19 th) tertinggi adalah Kalimantan Tengah (52,1\%), Jawa Barat (7,5 persen), serta Kalimantan Timur dan Kalimantan Tengah masing-masing 7 persen dan Banten 6,5 Persen Barat (50,2 persen), serta Kalimantan Selatan (48,4\%), Bangka Belitung (47,9\%) dan Sulawesi Tengah (46,3\%). Dalam kajian ini menunjukkan hasil bahwa akar masalah dari pernikahan dini dan kehamilan remaja adalah masalah sosial ekonomi. Kasus kehamilan remaja di Kabupaten Gunungkidul menempati urutan tertinggi di Daerah Istimewa Jogjakarta. Tahun 2013 sebanyak 650 kasus (rentang usia remaja 10-20 tahun). Pada 2014 sebanyak 350 kasus (rentang usia remaja 10-18 tahun). Dari 350 kasus persalinan remaja di Kabupaten Gunungkidul yang tertinggi terdapat di Kecamatan Saptosari yaitu 53 kasus, data ini didapatkan dari laporan Program Kesehatan Remaja di Bidang Kesehatan Keluarga Dinkes, 2014).

Tujuan dari penelitian ini adalah mengkaji pengaruh aktivitas seksual pranikah, ketaatan beragama dan sosial ekonomi sebagai faktor yang berpengaruh terhadap kehamilan remaja 12-19 tahun di Kecamatan Saptosari Kabupaten Gunung kidul. 


\section{METODE PENELITIAN}

Jenis penelitian yang digunakan dalam penelitian ini adalah analitik observasional dengan menggunakan metode survey dan pendekatan case control yaitu rancangan penelitian yang membandingkan kelompok kasus dan kelompok kontrol untuk mengetahui proporsi kejadian berdasarkan riwayat ada atau tidaknya paparan. Rancangan ini bersifat retrospektif yaitu melihat ke belakang kejadian yang berhubungan dengan kejadian kesakitan yang diteliti

Populasi penelitian adalah remaja Umur 12-19 tahun yang hamil dan tidak hamil di Kecamatan Saptosari Kabupaten Gunungkidul tahun 2015, sebanyak 33 remaja. Sebagai Populasi kontrol, seluruh remaja yang berkunjung ke klinik sehat di Puskesmas Saptosari Kabupaten Gunungkidul tahun 2015. Cara penentuan sampel dengan menggunakan teknik sampel simple random sampling.

Dalam penelitian ini menggunakan ratio 1 : 1, Jadi sampel pada penelitian ini adalah 23 kasus (remaja yang hamil) dan 23 kontrol (remaja yang tidak hamil). Penelitian ini akan di lakukan di Kecamatan Saptosari Kabupaten Gunungkidul pada bulan Februari-Desember 2015.

Sumber data yang digunakan pada penelitian ini adalah data sekunder dan data primer. Data sekunder diambil dari data yang ada di puskesmas Saptosari di bagian KIA tentang kehamilan remaja, data di klinik sehat untuk kunjungan remaja yang tidak hamil, dan data dari Dinas Kesehatan Kabupaten Gunungkidul bagian Kesejahteraan Keluarga pada program Kesehatan Remaja. Data primer yang didapatkan dengan melakukan wawancara dan in depth interview. Wawancara dilakukan sesuai dengan pedoman kuesioner.

Data hasil penelitian yang sudah di rekap dideskripsikan dengan Distribusi frekuensi, menghitung nilai mean, skor, gambar dan tabel. Analisis regresi logistik bertujuan untuk mengetahui variabel prediktor mana yang berpengaruh secara signifikan terhadap variabel respons. Dari hasil analisis regresi logistik sederhana didapatkan variabel independen yang berpengaruh signifikan terhadap variabel independen lalu dilakukan analisis logistik berganda terhadap variabel-variabel yang berpengaruh secara signifikan untuk mengetahui ada tidak nya hubungan antara variabel tersebut.

Rangkuman hasil wawancara in depth interview untuk variabel yang paling berpengaruh ditampilkan pada hasil penelitian.

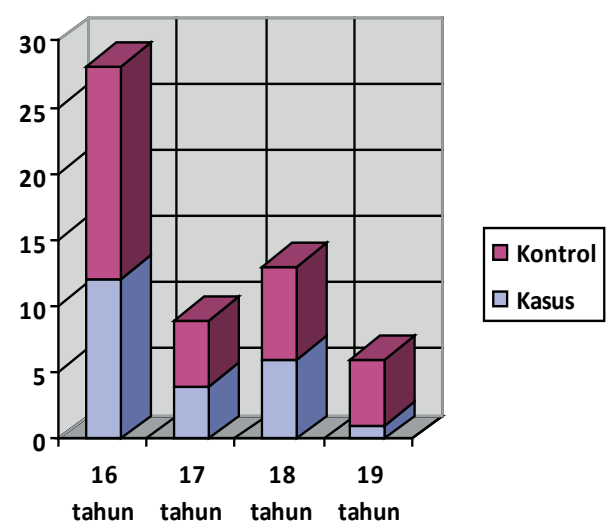

Gambar 1. Diagram Usia Remaja

\section{HASIL}

Penelitian dilakukan terhadap remaja putri yang hamil dan tidak hamil di Kecamatan Saptosari. Jumlah remaja putri yang diteliti adalah 23 remaja hamil dan 23 remaja yang tidak hamil. didapatkan karakteristik responden seperti di bawah ini:

Menurut gambar 1 usia remaja pada penelitian ini adalah 16-19 tahun. Pada kelompok kasus atau remaja yang hamil, usia yang terbanyak adalah 16 tahun atau sebesar 52\%

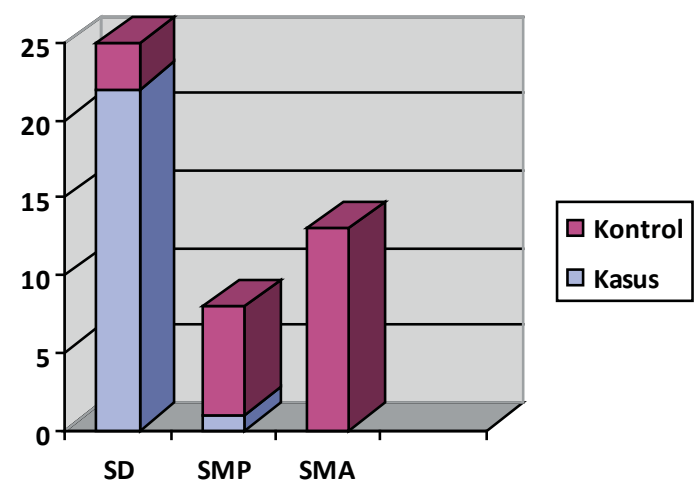

Gambar 2. Diagram Pendidikan Remaja 
dan usia yang paling sedikit adalah usia 19 tahun atau sebesar 4\%, Pada kelompok kontrol atau remaja yang tidak hamil usia terbanyak adalah 18 tahun atau sebesar $30 \%$, yang paling sedikit ada pada 2 kelompok usia yaitu usia 17 dan 19 tahun ( atau sebesar $22 \%$.

Menurut gambar 2. Pendidikan remaja pada penelitian ini adalah SD, SMP dan SMA. Pada kelompok kasus atau remaja yang hamil mayoritas remaja berpendidikan SD jumlah 22 responden atau sebesar $96 \%$, dan yang paling sedikit adalah berpendidikan SMP jumlah 1 responden atau sebesar $4 \%$, tidak ada responden kasus yang berpendidikan SMA. Pada kelompok kontrol atau remaja yang tidak hamil mayoritas remaja berpendidikan SMA sebanyak 57\%, dan yang paling sedikit adalah berpendidikan SD sebanyak $13 \%$.

Di bawah ini disajikan hasil penelitian yang dilaksanakan di Kecamatan Saptosari Kabupaten Gunungkidul yang berupa tabel terdiri dari tiga variabel penelitian yaitu aktivitas seksual pranikah, ketaatan beragama dan sosial ekonomi.

Menurut gambar tabel. 1 dalam penelitian menunjukkan bahwa aktivitas seksual terbanyak pada remaja kelompok kasus atau remaja yang hamil adalah buruk sebanyak 21 remaja atau $91 \%$, dan yang beraktivitas seksual baik sebanyak 2 remaja atau 9\%, aktivitas seksual terbanyak pada kelompok kontrol atau remaja yang tidak hamil adalah baik sebanyak 17 remaja atau $74 \%$ dan yang beraktivitas seksual buruk sebanyak 6 remaja atau 26\%. Ketaatan beragama terbanyak pada kelompok kasus adalah kurang taat beragama dan yang taat beragama hanya 1 remaja atau $4 \%$, ketaatan beragama pada kelompok kontrol atau remaja yang tidak hamil yang terbanyak adalah taat beragama sebanyak 19 remaja atau $83 \%$, yang kurang taat beragama sebanyak 4 remaja atau $17 \%$. Sosial ekonomi atau pengeluaran keluarga per bulan terbanyak pada kelompok kasus adalah < UMR sebanyak 18 remaja atau $78 \%$ dan yang sosial ekonomi diatas atau sama dengan UMR sebanyak 5 remaja atau $22 \%$. Untuk kelompok kontrol sosial ekonomi terbanyak adalah $\geq$ UMK sebanyak 20 remaja atau $87 \%$ dan yang sosial ekonomi $<$ UMK adalah 3 remaja atau $13 \%$.

\section{Rangkuman Hasil Wawancara Mendalam}

Berikut ini adalah hasil wawancara mendalam yang dilakukan terhadap responden penelitian untuk mendukung hasil analisis pada penelitian ini. Kondisi sosial ekonomi rendah pada remaja dalam penelitian ini menjadi alasan mereka untuk tidak melanjutkan sekolah dan menikah dini selain itu beban berganda pada remaja putri dan wanita pada umumnya di tempat penelitian adalah mengalami kekeringan dan kekurangan air bersih pada musim kemarau setiap tahunnya sehingga para remaja putri dituntut

Tabel 1. Hasil Penelitian

\begin{tabular}{|c|c|c|c|c|c|c|c|}
\hline & \multicolumn{2}{|c|}{ Kasus } & \multicolumn{2}{|c|}{ Kontrol } & \multirow{2}{*}{ Total } & \multirow{2}{*}{$\mathbf{P}$} & \multirow{2}{*}{ OR } \\
\hline & $f$ & $\%$ & $f$ & $\%$ & & & \\
\hline \multicolumn{8}{|c|}{ Aktivitas Seksual Pranikah } \\
\hline Baik & 2 & 9 & 17 & 74 & 19 & \multirow{3}{*}{0,00} & \multirow{3}{*}{29,7} \\
\hline Buruk & 21 & 91 & 6 & 26 & 27 & & \\
\hline Total & 23 & 100 & 23 & 100 & 46 & & \\
\hline \multicolumn{8}{|c|}{ Ketaatan Beragama } \\
\hline Taat beragama & 1 & 4 & 19 & 83 & 20 & \multirow{3}{*}{0,000} & \multirow{3}{*}{104,5} \\
\hline Kurang taat & 22 & 96 & 4 & 17 & 26 & & \\
\hline Total & 23 & 100 & 23 & 100 & 46 & & \\
\hline \multicolumn{8}{|l|}{ Sosial Ekonomi } \\
\hline$<\mathrm{UMK}$ & 18 & 78 & 3 & 13 & 21 & \multirow{3}{*}{0,000} & \multirow{3}{*}{24} \\
\hline$\geq \mathrm{UMK}$ & 5 & 22 & 20 & 87 & 87 & & \\
\hline Total & 23 & 100 & 23 & 100 & 46 & & \\
\hline
\end{tabular}


untuk mencari nafkah dan melakukan pekerjaan rumah tangga, bersekolah menurut mereka hanya sia-sia. Dengan alasan ini mayoritas remaja memutuskan untuk menikah muda dengan

Tabel 6. Hasil Analisis Multivariat

\begin{tabular}{lccc}
\hline Variabel Independen & B & P & OR \\
\hline Sosial ekonomi & & & \\
$\quad$ < UMK & 4,157 & 0.001 & 60 \\
$\quad$ U UMK (ref) & & & \\
Ketaatan beragama & & & \\
$\quad$ Tidak taat beragama & 4,05 & 0,006 & 57,772 \\
$\quad$ Taat beragama (ref) & - & - & \\
Constanta & $-1,201$ & 0,290 & \\
\hline
\end{tabular}

pertimbangan dapat meringankan beban orang tua dan terbebas dari himpitan ekonomi.

\section{Analisis Multivariat Faktor Risiko Kehamilan Remaja di Kecamatan Saptosari}

Dari hasil analisis regresi berganda didapatkan bahwa ada pengaruh sosial ekonomi terhadap kehamilan remaja dengan $\mathrm{P}$ Value sebesar 0,001, angka ini lebih kecil dari $\alpha$ sebesar 0,05 . Dengan OR sebesar 60 yang berarti remaja dengan sosial ekonomi atau jumlah pengeluaran keluarga per bulan < UMK berisiko $60 \mathrm{kali}$ lebih besar untuk terjadi kehamilan remaja dibandingkan dengan responden dengan sosial ekonomi atau pengeluaran keluarga per bulan $\geq$ UMK. Ada pengaruh ketaatan beragama terhadap kehamilan remaja dengan signifikansi 0,006 angka ini lebih kecil dari $\alpha$ sebesar 0,05 , dengan OR 57,772 yang berarti responden yang tidak taat beragama berisiko 57 kali lebih besar untuk terjadi kehamilan dibandingkan dengan responden yang taat beragama. Sedangkan untuk aktivitas seksual pranikah didapatkan hasil tidak ada pengaruh terhadap kehamilan remaja karena adanya variabel lain yang sangat dominan.

\section{PEMBAHASAN}

\section{Pengaruh Faktor Aktivitas Seksual Pranikah terhadap Kehamilan Remaja}

Pada analisis univariat didapatkan ada pengaruh aktivitas seksual pranikah terhadap kehamilan remaja dengan OR 9,7 yang berarti responden dengan perilaku seksual yang buruk memiliki risiko 29,7 kali lebih besar untuk terjadi kehamilan dibandingkan dengan responden dengan perilaku seksual pranikah yang baik. Namun setelah dilakukan analisis regresi multivariat didapatkan hasil yang tidak signifikan atau tidak ada pengaruh aktivitas seksual pranikah terhadap kehamilan remaja pada penelitian ini. Hal ini dimungkinkan karena salah satu variabel hubungannya sangat erat, maka dimungkinkan variabel lain akan menjadi tidak signifikan lagi pengaruhnya terhadap variabel respons.

Aktivitas seksual pranikah pada penelitian ini tidak berpengaruh karena setelah dilakukan analisis regresi pada semua variabel, terdapat variabel yang sangat kuat pengaruhnya yaitu sosial ekonomi sehingga variabel perilaku seksual pranikah yang pengaruhnya lebih kecil tersisih dalam analisis multivariat.

Data dari Bennet (2003), menunjukkan bahwa dari 3 Studi yang dilakukan tentang Program abstinensi pada remaja di sekolah menekankan pentingnya penggunaan kondom untuk remaja yang aktif melakukan hubungan seksual di luar nikah. Hal ini dilakukan untuk mencegah kehamilan remaja akibat perilaku seksual di luar nikah dan rendah nya tingkat abstinensi pada remaja.

Hasil penelitian yang dilakukan oleh Jewkes (2002), di Afrika Selatan menunjukkan bahwa seksualitas remaja menyebabkan risiko klinis obstetrik kehilangan kesuburan pada remaja. Kehamilan remaja sangat umum di Afrika Selatan, pola aktivitas seksual remaja sangat tinggi dan menempatkan remaja pada risiko HIV karena 1 dari 5 remaja hamil terinfeksi HIV.

BKKBN (2015), melalui Sub Bidang Ketahanan Remaja menyatakan bahwa buruknya aktivitas seksual pranikah remaja dan kehamilan remaja merupakan dilema untuk menutup malu orang tua memilih untuk menikahkan tapi tidak sedikit pasangan remaja yang memilih untuk melakukan aborsi hal ini dibuktikan dengan meningkatnya angka aborsi di kalangan remaja.

Pentingnya pendidikan kesehatan reproduksi remaja untuk meningkatkan pengetahuan remaja tentang akibat dari aktivitas seksual remaja 
yang dapat menyebabkan kehamilan yang tidak diinginkan, aborsi yang dapat mengakibatkan perdarahan dan kematian, dan penyakit menular seksual.

\section{Pengaruh Ketaatan beragama terhadap Kehamilan Remaja}

Hasil pada penelitian menunjukkan ada pengaruh ketaatan beragama terhadap kehamilan remaja hal ini sesuai dengan pernyataan bahwa penanaman akidah tauhid (keimanan) dan mempraktikkan diri dengan terapi sholat, puasa, mengeluarkan zakat dan membiasakan zikir bertujuan untuk penguatan unsur keimanan, ketaatan dan ketakwaan tertanam kuat dalam jiwa manusia, keimanan merupakan kekuatan rohaniah yang memengaruhi pola dasar kecenderungan dalam berpikir dan berperilaku (Dadang, 2010).

Penelitian terhadap faktor yang memengaruhi seksual pranikah pada mahasiswa di Akademi kesehatan di Banten oleh Sinaga tahun 2013 disimpulkan bahwa ketaatan anak dan remaja dalam menjalankan ibadah menurut agamanya sangat berpengaruh besar dalam pengendalian perilaku anak dan remaja itu sendiri termasuk di dalamnya perilaku seksual. Remaja yang taat beragama memilki kontrol diri dan mampu menjaga perilakunya saat berhadapan dengan lawan jenis.

Pengaruh ketaatan beragama terhadap kehamilan remaja ini juga didukung oleh Salihun (2002) yang menyatakan bahwa remaja dengan religiusitas tinggi akan memandang agamanya sebagai tujuan utama hidupnya sehingga berusaha menerapkan ajaran agama dalam perilaku seharihari dan memiliki batasan yang kuat dalam dirinya sehingga dorongan seksual berupa penyaluran hasrat seksual tidak membuat diri seseorang melakukan seks bebas yang dilarang oleh agamanya.

Hasil penelitian ini juga sesuai penelitian yang dilakukan oleh Hajar (2015), di Kota Jogjakarta yang menyatakan bahwa terdapat hubungan negatif yang signifikan antara ketaatan beragama dengan aktivitas seksual pranikah pada remaja, Semakin remaja taat beragama semakin rendah kecenderungan untuk melakukan aktivitas seksual di luar nikah.

\section{Pengaruh Sosial Ekonomi terhadap Kehamilan Remaja}

Hasil penelitian ini menunjukkan ada pengaruh sosial ekonomi terhadap kehamilan remaja hal ini sejalan dengan Data UNICEF (2010), menyebutkan bahwa pernikahan anak berkaitan dengan tradisi dan budaya, dan alasan ekonomi, Harapan mencapai keamanan sosial dan finansial setelah menikah menyebabkan banyak orang tua mendorong anaknya untuk menikah di usia muda. Keputusan remaja putri untuk menikah seringkali dibuat oleh orang tua atau masyarakat. Pada umumnya remaja putri di pedesaan dengan sosial ekonomi rendah setelah putus sekolah mereka merantau ke kota untuk mencari pekerjaan sebagai buruh atau pembantu rumah tangga. Pendidikan rendah, keterampilan kurang menyebabkan mereka hanya mendapatkan pekerjaan kasar.

Dengan menikah di usia muda mereka dan orang tua percaya akan membantu melengkapi fungsi sosial, perlindungan dan menjamin stabilitas ekonomi untuk anak perempuan dan keluarga. Penelitian oleh Anjarwati (2009), menyatakan bahwa status sosial ekonomi berhubungan secara signifikan dengan perilaku seksual remaja ( $\mathrm{RP}=1,5$; CI $95 \%=1,15-2,05)$ dengan kesimpulan bahwa prevalensi remaja dengan status sosial ekonomi rendah memiliki perilaku seksual yang lebih tinggi dibandingkan dengan remaja yang berstatus sosial ekonomi yang lebih tinggi.

Marjorie (2011), menyebutkan bahwa remaja dengan tingkat ekonomi rendah rentan terjadi kehamilan, dan program peningkatan ekonomi memberi manfaat signifikan untuk menghindari atau mencegah kehamilan remaja. Program pencegahan kehamilan remaja yang dilaksanakan secara kompleks menyangkut pengembangan pendidikan, keterampilan hidup, dan meningkatkan ekonomi keluarga memberikan nilai efektif dalam mencegah kehamilan di kalangan remaja.

Kajian yang dilakukan oleh BKKBN 2012 di 4 propinsi yaitu Kalimantan Selatan, Sulawesi Tengah, Bangka dan Jawa Barat menyatakan bahwa akibat dari rendahnya kualitas kependudukan dari sisi sosial ekonomi berdampak pada kecenderungan tingginya angka pernikahan dini terkait perilaku seksual 
remaja. Hal ini mendukung hasil pada penelitian ini yang di mana sosial ekonomi berpengaruh pada kehamilan remaja.

Penelitian oleh Anjarwati 2009 pada siswa SMA negeri di Gunungkidul menunjukkan jumlah remaja dengan status sosial ekonomi yang tidak memadai memiliki kecenderungan berperilaku seksual di luar nikah dan terjadi kehamilan yang tidak diinginkan lebih tinggi dibandingkan remaja yang memiliki status sosial ekonomi yang lebih memadai

Penelitian ini didukung Jennifer Gaudie (2010) tentang faktor yang berhubungan dengan risiko tinggi kehamilan remaja, ketergantungan ekonomi, dan memiliki status ekonomi yang rendah, anak-anak dari ibu remaja cenderung memiliki potensi untuk mengulangi siklus kehamilan remaja. Kehamilan remaja terkait erat dengan pendidikan dan sosial ekonomi yang rendah, remaja yang hidup dalam kemiskinan, ketergantungan secara ekonomi dan mengalami kehamilan dapat meningkatkan risiko kematian ibu dan bayi karena tidak dapat membuat keputusan untuk menyelamatkan dirinya sendiri dan bayinya.

Hasil penelitian ini menunjukkan ada perbedaan yang signifikan antara sosial ekonomi remaja pada kelompok kasus dan kelompok kontrol. Mayoritas kategori pengeluaran keluarga perbulan < UMR sebanyak 17 responden (74\%) untuk kelompok kasus. Sedangkan untuk kelompok kontrol yang terbanyak yaitu dengan kategori $\geq$ UMR sebanyak 15 responden (65\%). Remaja pada kelompok kasus atau remaja yang hamil mayoritas berasal dari keluarga dengan sosial ekonomi yang pengeluaran keluarga per bulannya di bawah UMK. Keluarga miskin merasa tidak memiliki biaya untuk menyekolahkan anaknya ke jenjang yang lebih tinggi dan mengizinkan anak mereka untuk mencari pekerjaan untuk meringankan beban keluarga, Masyarakat dan lingkungan sekitar mendukung anak perempuan untuk menikah muda dan beranggapan tidak ada gunanya anak perempuan bersekolah karena akhirnya akan kembali ke dapur. Faktor ini berhubungan dengan rendahnya status ekonomi keluarga. Anggapan bahwa jika seorang remaja putri sudah menikah, maka tanggung jawabnya akan dialihkan kepada suaminya.

\section{SIMPULAN DAN SARAN}

\section{Simpulan}

Tidak ada pengaruh Aktivitas Seksual Pranikah terhadap kehamilan remaja 12-19 tahun di Kecamatan Saptosari Kabupaten Gunungkidul.

Ada pengaruh ketaatan beragama terhadap kehamilan Remaja di Kecamatan Saptosari Kabupaten Gunungkidul. Remaja yang tidak taat beragama berisiko 58 kali lebih besar untuk terjadi kehamilan di banding dengan remaja yang taat beragama

Ada pengaruh Sosial Ekonomi sebagai terhadap kehamilan Remaja di Kecamatan Saptosari Kabupaten Gunungkidul. Remaja dengan sosial ekonomi atau jumlah pengeluaran keluarga perbulan $<$ UMK berisiko 63 kali lebih besar dibanding dengan remaja dengan sosial ekonomi $\geq$ UMK.

\section{Saran}

Hasil penelitian ini diharapkan menjadi bahan informasi untuk mengkaji masalah kehamilan remaja lebih mendalam pada penelitian selanjutnya, dijadikan referensi dan masukan tentang masalah kehamilan remaja. Terkait sosial ekonomi mungkin diperlukan untuk menyediakan beasiswa sekolah bagi remaja yang tidak mampu, meningkatkan motivasi remaja putri untuk melanjutkan sekolah dan untuk ketaatan beragama diharapkan diadakan kegiatankegiatan keagamaan bagi remaja putri seperti kelompok pengajian remaja yang didalamnya dapat disisipkan kegiatan penyuluhan kesehatan reproduksi bagi remaja putus sekolah.

\section{DAFTAR PUSTAKA}

Arikunto 2010. Prosedur Penelitian Suatu Pendekatan Praktik. Jakarta, Rineka Cipta.

Anjarwati 2009. Penelitian Hubungan status sosial ekonomi dengan perilaku seksual remaja pada siswa SMA Negeri di Kabupaten Gunung Kidul. Thesis UGM 2009

BKKBN 2010. Remaja, Genre dan Perkawinan dini. Jakarta,

BKKBN 2012. Kajian Pernikahan Dini di Propinsi Kalimantan Selatan, Sulawesi Tengah, Bangka dan Jawa Barat 2012. 
BKKBN SULUT 2015, Angka Remaja Hamil, Seks bebas, HIV dan Narkotika.

Budiarto 2004. Metodologi Penelitian Kedokteran. Jakarta EGC 2004

Badan Pusat Statistik 2010. Profil Penduduk Remaja. [online]. Last accessed 24 may 2015 at: HYPERLINK "www.bps.go.id" www. bps.go.id

Bennet 2003. School-based teenage pregnancy prevention programs: A systematic review of randomized controlled trials 2003

Badan pusat statistik Gunungkidul 2009. In: kecamatan Saptosari dalam angka Saptosari district in figures 2009. Gunungkidul.

Dadang, H 2010. Alqur 'an Ilmu kedokteran Jiwa dan kesehatan Jiwa. Yogyakarta, PT dana Bhakti Primayasa.

Dinas Kesehatan Kabupaten Gunungkidul 2015. Laporan Bulanan Program Kesehatan Remaja 2015

Gaudie, BMC Public Health 2010. Antecedents of teenage pregnancy from a 14-year follow-up study using data linkage

Hidayat 2010. Metode Penelitian Kebidanan dan Teknik Analisis Data. Jakarta, Salemba Medika.

Jewkwes 2001. Relationship dynamics and teenage pregnancy in South Africa 2002

Martinez G 2011. Teenagers in the United States: sexual activity, contraceptive use, and childbearing, 2006-2010 national survey of family growth.

Marjorie 2011. Economic Evaluation of a Comprehensive Teenage Pregnancy Prevention Program: Pilot Program

Hajar 2015. Hubungan Antara Sikap Beragama Dengan Kecenderungan Perilaku Seksual Pra Nikah.

Salihun, A N 2002. Peran Pendidikan Agama terhadap Pemecahan Problem Remaja. Jakarta, Kalam Mulia.

SDKI (2010). Kependudukan dan Kesehatan Angka Kematian Ibu dan Angka Kematian Bayi. [online]. Last accessed 3 April 2015.

Sinaga 2012. Faktor-Faktor yang memengaruhi perilaku seks pranikah pada mahasiswa di akademi kesehatan X di Kabupaten Lebak.

The Nation's Health 2007. Teen pregnancy prevention focusing on evidence: Ineffective abstinence-only lessons being replaced with science. American Public Health Association

UNICEF 2012. child Protection information sheet. [online]. Last accessed 4 May 2015 at:

UNICEF 2006. Early marriage: a harmful traditional practice, a statistical exploration. [online]. Last accessed 29 April 2015

Unicef 2010. child Protection information sheet. [online]. Last accessed 4 May 2015 at: hyperlink www.unicef.0rg

World health Organization 2010. Maternal Mortality Country Profiles. 